\title{
MERCATORIA
}

Available online http://ojs.uma.ac.id/index.php/mercatoria

\section{Analisa Yuridis Penyidikan Tindak Pidana Illegal Logging oleh Polres Tapanuli Tengah}

\author{
Azuar Anas, Marlina * \\ Panit 1 Unit 1 Subdit 1 Ditreskrimum Polda Sumut \\ Universitas Sumatera Utara \\ *Corresponding author: E-mail: azuaranas88@yahoo.com, linafulinsia@yahoo.com
}

\begin{abstract}
Abstrak
Pembalakan Liar (Illegal Logging) secara besar-besaran dengan menggunakan peralatan modern biasanya sebagai pemicu kerusakan hutan dan menimbulkan bencana alam terutama longsor dan banjir, tetapi penebangan pohon kayu di dalam kawasan hutan lindung Desa Simaningir Kec. Sitahuis Kabupaten Tapanuli Tengah menggunakan alat berupa chain saw saja, dapat menimbulkan bencana alam tanah longsor dan menimpa rumah penduduk. Penyidik Polres Tapanuli Tengah telah mengungkap penyebab tanah longsor yaitu karena penebangan pohon kayu secara Illegal di dalam kawasan hutan lindung, selanjutnya penyidik Polres Tapanuli Tengah melakukan penyelidikan dan penyidikan terhadap pelaku penebangan pohon kayu. Faktor yang mempengaruhi sulit mengungkap kasus Illegal Logging adalah lemahnya peraturan perundang-undangan, sarana dan prasarana yang kurang memadai, mentalitas aparat dan budaya masyarakat.
\end{abstract}

Kata kunci : Illegal Logging, Tindak Pidana

\begin{abstract}
Illegal Logging on a large scale using modern equipment usually as a trigger deforestation and caused natural disasters, especially landslides and floods.but felling trees in the protected forest area using the tool like chain saw, it can inflict natural disasters landsliders and hit houses of people around. The investigators of the Police Central Tapanuli have revealed the cause of the landslide is due to felling of trees, furthermore investigators conduct investigations agains perpetrators of timber extraction. Factors affecting the hand uncovering cases is the lack of laws and regulations, infrastructure in adequate, apparatus mentality and culture of people.
\end{abstract}

Keyword: Illegal Logging, Criminal Act

How to Cite: Anas, A., dan Marlina, (2018), Analisa Yuridis Penyidikan Tindak Pidana Illegal Logging oleh Polres Tapanuli Tengah, Mercatoria, 11 (1): 61-73. 
Azuar Anas dan Marlina, Analisa Yuridis Penyidikan Tindak Pidana Illegal Logging oleh Polres Tapanuli Tengah

\section{PENDAHULUAN}

Perkembangan budaya serta peradaban dari waktu ke waktu menimbulkan beberapa dampak yang positif maupun negatif. Akibat dari perkembangan pandangan yang berlebihan juga menimbulkan persaingan antar manusia, kerakusan pun terjadi yang menghalalkan segala cara untuk memenuhi kebutuhan yang diinginkan

Salah satu contoh terjadinya kejadian tanah longsor pada hari Kamis tanggal 27 April 2012 pukul 16.00 Wib di Jln. Tarutung Km. 5 yang yang menimpa dua unit rumah masyarakat sehingga rusak, sehingga jalan umum menjadi tertimbun oleh tanah dan lumpur, mengakibatkan jalan umum dari Medan ke Sibolga dan sebaliknya terputus. Penyebab tanah longsor diduga akibat penebangan pohon kayu di lereng perbukitan sekitar 300 meter dari jalan raya. Berdasarkan keterangan penduduk setempat bahwa yang menebang pohon kayu adalah Judiman Pardede. Berdasarkan keterangan penyidik yang (Idris, Saring, 1993) menangani tindak pidana Illegal Logging atas nama Bripka Bagus Seto, Sh Personel Sat Reskrim Polres Tapanuli Tengah sebagai tersangka yang melakukan penebangan pohon kayu adalah Judiman Pardede. Dalam perkara ini ada dua orang tersangka yaitu Judiman Pardede yang melakukan penebangan pohon kayu dan Parasian Tarihoran (Kepala Desa Simaninggir yang menerbitkan Surat Keterangan Tanah) di dalam kawasan hutan lindung kepada tersangka Judiaman Pardede. Bahwa Kepala Desa Tidak dapat menerbitkan Surat Keterangan Tanah Ketentuan pasal 24 Peraturan Pemerintah
No.24 Tahun 1997 tentang Pendaftaran Tanah menyebutkan bahwa untuk keperluan pendaftaran tanah yang berasal dari hak-hak atas tanah yang berasal dari konversi hak-hak lama dibuktikan dengan alat-alat bukti mengenai adanya hak tersebut berupa bukti-bukti tertulis, keterangan saksi dan atau pernyataan yang bersangkutan, dengan demikian dalam rangka pembuktian hak milik adat tersebut di daerah Tapanuli Tengah apabila tidak ada bukti tertulis tentang kepemilikannya maka seseorang yang merasa memiliki sebidang tanah tersebut dapat membuat surat pernyataan kepemilikan tanah, yang disaksikan oleh sekurang-kurangnya 2 (dua) orang saksi dan diketahui Kepala Desa (sesuai pasal 76 ayat 2 Peraturan Menteri Negara Agraria/Kepala Badan Pertanahan Nasional (Data Polres Tapanuli Tengah dalam perkara Illegal Logging).

Berdasarkan latar belakang sebagaimana dikemukakan di atas, maka perumusan masalah dalam penelitian ini adalah :

1. Bagaimanakah Pengaturan Penyidikan tindak pidana Illegal Logging?

2. Bagaimanakah Peran Penyidik Polres Tapanuli Tengah Terhadap Kejadian Penebangan Pohon Kayu di Dalam Kawasan Hutan di Kecamatan Sitahuis Kab.Tapanuli Tengah?

3. Faktor apa sajakah yang mempengaruhi Penyidikan tindak pidana Illegal Logging oleh Penyidik Polres Tapanuli Tengah?

\section{METODE PENELITIAN}

Jenis penelitian ini bersifat yuridis normative yaitu menggambarkan 
menelaah dan menjelaskan serta menganalisa ketentuan-ketentuan normative dikaitkan dengan tindak pidana Illegal Logging yang terjadi di daerah kabupaten Tapanuli Tengah. Penelitian dilakukan bertujuan untuk meneliti kaidah-kaidah yang terkandung dalam peraturan perundang-undangan yang berlaku. Pengumpulan data berkaitan dengan sumber daya karena melalui pengumpulan data akan diperoleh data yang diperlukan untuk selanjutnya dianalisis sesuai dengan yang di harapkan (Soekanto Soeryono, 2012). Adapun beberapa bahan hukum tersebut adalah sebagai berikut: Bahan hukum primer, bersumber dari bahan hukum yang diperoleh langsung dan akan digunakan dalam penelitian yang merupakan bahan hukum yang mempunyai kekuatan mengikat secara yuridis (Soekanto Soeryono, 2012), yaitu KUH Pidana, Undang-Undang Nomor 32 Tahun 2009 tentang Perlindungan dan Pengelolaan Lingkungan Hidup, Instruksi Presiden Nomor 4 Tahun 2005 tentang Pemberantasan Penebangan Kaya Secara Illegal di Kawasan Hutan.

\section{HASIL DAN PEMBAHASAN}

Kejadian tindak pidana Illegal Logging yang terjadi di wilayah hukum Polres Tapanuli Tengah lima tahun terakhir yaitu dari tahun 2012 sampai dengan tahun 2016 sebanyak 43 (empat puluh tiga) kasus. Kejadian terbanyak pada tahun 2012, sedangkan pada tahun 2016 tidak ada laporan mengenai Tindak Pidana Illegal Logging.

Berdasarkan data dari Polres Tapanuli Tengah terdapat kejadian tindak pidana Illegal Logging di wilayah hukum
Polres Tapanuli Tengah cenderung menurun dari tahun ke tahun, tetapi pada tahun 2015 kembali naik jumlahnya. Menurut keterangan Staf Unit Tindak Pidana Tertentu Sat Reskrim Polres Tapanuli Tengah atas nama Bripka Bagus Seto, Sh, bahwa data tersebut adalah data dari seluruh Wilayah Polres Tapanuli Tengah, termasuk dari Polsek.

Pada tahun 2016 Polres Tapanuli Tengah tidak ada melakukan penyidikan tindak pidana Illegal Logging. Penyebabnya karena tidak ada laporan tindak pidana Illegal Logging yang diterima oleh Polres Tapanuli Tengah.

\section{Pengaturan Penyidikan Tindak Pidana Illegal Logging}

Pembalakan liar (Illegal Logging) adalah rangkaian kegiatan dalam bidang kehutanan dalam rangka pemanfaatan dan pengelolaan hasil hutan kayu yang bertentangan dengan aturan hukum yang berlaku dan atau berpotensi merusak hutan. Esensi yang penting dalam praktik pembalakan liar (Illegal Logging) ini adalah perusakan hutan yang akan berdampak pada kerugian baik dari aspek ekonomi, ekologi maupun sosial budaya. Oleh karena kegiatan itu tidak melalui proses perencanaan secara komprehenshif, maka pembalakan liar (Illegal Logging) mempunyai potensi merusak hutan yang kemudian berdampak pada perusakan lingkungan. Terkait dengan perusakan lingkungan hidup secara tegas disebutkan dalam Undang-Undang Nomor 32 Tahun 2009 tentang Perlindungan dan Pengelolaan Lingkungan Hidup Pasal 1 butir 16 berbunyi " Perusakan lingkungan hidup adalah tindakan orang yang menimbulkan 
perubahan langsung atau tidak langsung terhadap sifat fisik, kimia, dan/atau hayati lingkungan hidup sehingga melampaui kriteria baku kerusakan lingkungan hidup. "Kerusakan hutan menurut UndangUndang No. 41 tahun 1999 dalam penjelasan Pasal 50 Ayat (2), yaitu bahwa "Yang dimaksud dengan kerusakan adalah terjadinya perubahan fisik, sifat fisik atau hayatinya, yang menyebabkan hutan tersebut terganggu atau tidak dapat berperan sesuai dengan fungsinya."

Istilah "Kerusakan hutan" yang dimuat dalam peraturan perundangundangan dibidang kehutanan yang berlaku ditafsirkan bahwa kerusakan hutan mengandung pengertian yang bersifat dualisme yaitu pertama, kerusakan hutan yang berdampak positif dan memperoleh persetujuan dari pemerintah tidak dapat dikategorikan sebagai perbuatan yang melawan hukum. Kedua, kerusakan yang berdampak negatif (merugikan) adalah suatu tindakan nyata melawan hukum dan bertentangan dengan kebijaksanaan atau tanpa adanya persetujuan pemerintah dalam bentuk perizinan (Hasanah, Sovia, 2016). Sebagaimana diketahui bahwa setiap pembangunan akan membawa dampak terhadap perubahan lingkungan terutama eksploitasi sumber daya hutan dalam rangka pengelolaan dan pemanfaatan hasil hutan jelas akan menimbulkan efek dari perubahan dari perubahan kondisi hutan tersebut. Dengan kata lain bahwa eksploitasi sumber daya hutan itu merupakan salah satu bentuk dari perusakan hutan.

Dengan demikian maka dituntut adanya aparatur penegak hukum yang memiliki kemampuan profesional, menjunjung tinggi kejujuran, kebenaran dan keadilan, bersih, berwibawa dan bertanggungjawab. Kepatuhan terhadap hukum yang dilandasi adanya kesadaran hukum yang tinggi serta keikhlasan untuk mematuhinya adalah merupakan prasyarat tidak terjadinya pelanggaran hukum. Selain itu diperlukan adanya sikap dari pelaksana penegak hukum yang obyektif, tidak memihak yang sesuai dengan prinsip keadilan.

Kepolisian Negara Republik Indonesia selaku alat negara penegak hukum sesuai dengan Pasal 14 ayat (1) huruf g Undang-Undang Nomor 2 Tahun 2002, tentang Kepolsian Negara RI berbunyi " melakukan penyelidikan dan penyidikan terhadap semua tindak pidana sesuai dengan hukum acara pidana dan peraturan perundang-undangan lainnya.

Hukum dan perundang-undangan yang menjadi porsi tugas Polri untuk ditegakkan adalah semua hukum pidana baik yang tercantum dalam KUHP maupun di luar KUHP termasuk Peraturan Daerah.

Upaya penegakan hukum melalui suatu proses penyidikan perkara tersebut pada hakekatnya adalah merupakan suatu tindakan yang bersifat pembatasan, pengekangan hak-hak asasi seseorang dalam rangka usaha untuk memulihkan terganggunnya keseimbangan antara kepentingan umum guna terpeliharanya keamanan dan ketertiban masyarakat.

Pasal 6 ayat (1) KUHAP menyebutkan bahwa ada dua pejabat yang diberikan wewenang sebagai Penyidik tindak pidana kehutanan, yaitu Penyidik Polri dan Penyidik Pegawai Negeri Sipil (PPNS). Penyidik Polri memiliki kewenangan sebagaimana yang disebutkan dalam Pasal 7 ayat (1) KUHAP 
sedangkan untuk PPNS kewenangannya sesuai dengan undang-undang yang menjadi dasar hukumnya masing-masing, untuk PPNS kehutanan kewenangannya diatur dalam Pasal 77 Undang-undang No 41 tahun 1999 tentang Kehutanan dan Pasal 39 Undang-undang Nomor 5 tahun 1990 tentang Konservasi Sumber Daya Alam dan Ekosistemnya. Tugas penyidik polri dalam melaksanakan penyidikan tindak pidana kehutanan sesuai Peraturan Kapolri No. 20 tahun 2010 tentang Koordinasi, Pengawasan dan Pembinaan Penyidikan Bagi Penyidik Pegawai Negeri Sipil (PPNS).

Kejahatan penebangan liar (Illegal Logging), dengan pemberian sanksi pidana yang merupakan salah satu dari upaya perlindungan hutan dalam rangka mempertahankan fungsi hutan secara lestari. Maksud dan tujuan dari pemberian sanksi pidana yang berat terhadap setiap orang yang melanggar hukum di bidang kehutanan (termasuk melakukan penebangan liar) ini adalah dapat menimbulkan efek jera bagi pelangaran hukum di bidang kehutanan. Efek jera yang dimaksud bukan hanya kepada pelaku yang telah melakukan tindak pidana kehutanan, tetapi kepada orang lain yang mempunyai kegiatan dalam bidang kehutanan menjadi enggan dan harus berpikir berkali-kali untuk melakukan perbuatan melanggar hukum karena sanksi pidananya berat (Marpaung, Leden, 2005).

Para penyidik kemudian menuangkan hasil penyidikan tersebut kedalam Berita Acara Pemeriksaan (BAP). BAP ini kemudian diserahkan oleh penyidik kepada penuntut umum untuk dipelajari dan diteliti kelengkapannya sebagai dasar untuk membuat surat dakwaan. Menurut pasal 38 KUHAP, penuntut umum mengembalikan BAP tersebut kepada penyidik apabila penuntut umum menilai bahwa BAP tersebut belum lengkap Pengembalian tersebut disertai petunjuk tentang hal yang harus dilakukan untuk dilengkapi oleh penyidik dalam waktu 14 hari setelah penerimaan berkas. Apabila penuntut umum menilai bahwa BAP tersebut telah lengkap, maka penuntut umum kemudian akan membuat surat dakwaan dan dilanjutkan ke tahap penuntutan (Soerodibroto, Soenarto, 2007). Pasal 1 butir 7 KUHAP menyatakan bahwa penuntutan adalah melimpahkan perkara pidana ke Pengadilan Negeri yang berwenang dalam hal dan menurut cara yang diatur dalam KUHAP dengan permintaan supaya diperiksa dan diputus hakim di sidang pengadilan.

\section{Peran Penyidik Polres Tapanuli} Tengah terhadap Kejadian Penebangan Pohon Kayu di Dalam Kawasan Hutan di Kecamatan Sitahuis Kab. Tapanuli

\section{Tengah}

Hukum acara pidana sebagai hukum pelaksana dari hukum pidana mempunyai kedudukan yang sangat penting dimana semua aturan yang diatur dalam hukum acara pidana mempunyai peranan yang penting bagi penegakan setiap normanorma yang telah diatur dalam hukum pidana. Pada hukum acara pidana sendiri berisi mengenai hal-hal yang bersangkutan dengan proses bagaimana seseorang yang sudah memenuhi rumusan tindak pidana dari undang-undang dapat dijatuhi hukuman atau pidana. Dimana salah satu proses yang penting yang 
Azuar Anas dan Marlina, Analisa Yuridis Penyidikan Tindak Pidana Illegal Logging oleh Polres Tapanuli Tengah

menjadi kajian dalam hukum acara pidana adalah penyidikan sebagaimana yang diiyakan oleh para ahli hukum yang menyatakan bahwa adanya proses penyidikan dalam pengungkapan suatu tindaka pidana merupakan bagian yang tak terpisahkan dalam mencari titik terang mengenai siapa yang menjadi pelakunya (Supriadi, 2010). Adanya proses penyidikan tersebut diatas merupakan konsekuensi karena untuk menegakkan aturan hukum pidana maka terlebih dahulu harus ada tindak pidana yang telah dilakukan oleh seseorang. Padahal Tindak Pidana adalah suatu perbuatan yang dilakukan oleh seseorang dimana perbuatan tersebut melanggar ketentuan perundang-undangan yang diancam dengan sanksi terhadap pelanggaran tersebut, dimana perbuatan yang melanggar ketentuan perundangan tersebut melahirkan sanksi yang bersifat pidana, sanksi bersifat perdata, ataupun sanksi yang bersifat administrasi. Menurut Pasal 1 angka 2 KUHAP Penyidikan adalah serangkaian tindakan penyidik dalam hal dan menurut cara yang diatur dalam undang-undang ini untuk mencari serta mengumpulkan bukti yang dengan bukti itu membuat terang tentang tindak pidana yang terjadi dan guna menemukan tersangkanya.

Berdasarkan keempat unsur tersebut dapat disimpulkan bahwa sebelum dilakukan penyidikan, telah diketahui adanya tindak pidana tetapi tindak pidana itu belum terang dan belum diketahui siapa yang melakukannya. Adanya tindak pidana yang belum terang itu diketahui dari penyilidikannya. Oleh sebab itu penyidikan merupakan ujung tombak pengungkapan suatu tindak pidana
(Suarga, Riza. 2005). Guna mencapai tujuan hukum acara pidana yaitu mencari dan menemukan kebebaran materiil, maka beban pencarian untuk menemukan alatalat bukti yang akan digunakan oleh penuntut umum dipersidangan ada dipundak penyidik. Maka dari itu dalam pelaksanaan proses penyidikan, penyidik harus memperhatikan asas-asas hukum acara sebagaimana terdapat dalam KUHAP.

Dengan demikian penyidikan merupakan suatu proses atau langkah awal yang merupakan suatu proses penyelesaian suatu tindak pidana yang perlu diselidik dan diusut secara tuntas didalam system peradilan pidana, dari pengertian tersebut (Hamzah, Andi. 2004), maka bagian-bagian dari hukum acara pidana yang menyangkut tentang penyidikan adalah sebagai berikut: ketentuan-ketentuan tentang alat-alat bukti, ketentuan tentang terjadinya delik, pemeriksaan ditempat kejadian, pemanggilan tersangka atau terdakwa, penahanan sementara, penggeledahan, pemeriksaan dan introgasi, berita acara, pelimpahan perkara kepada Penuntut Umum dan pengembalian kepada penyidik untuk disempurnakan. Dalam sistem KUHAP kewenangan penyelidikan ada pada pejabat polisi Negara (Pasal 4 KUHAP), sedangkan kewenangan penyidikan ada pada pejabat polisi Negara dan Penyidik Pegawai Negeri Sipil yang syarat kepangkatannya diatur dalam peraturan pemerintah (Pasal 6 ayat (1) dan ayat (2) KUHAP). Menurut ketentuan Pasal 1 angka1 KUHAP, Penyidik adalah pejabat polisi negara Republik Indonesia atau pejabat pegawai negeri sipil tertentu yang diberi wewenang khusus oleh 
undang-undang untuk melakukan penyidikan. Menurut Pasal 6 ayat (1) KUHAP menyebutkan bahwa ada dua pejabat yang berkedudukan sebagai Penyidik, yaitu Penyidik Polri dan Penyidik Pegawai Negeri Sipil (PPNS). Khusus pengangkatan pegawai negeri sipil di lingkungan kepolisian menjadi pejabat penyidik pembantu, yang bersangkutan harus mempunyai keahlian atau kekhususan dalam bidang tertentu. Tanpa syarat tersebut, tidak ada alasan atau urgensi untuk mengangkat mereka menjadi pejabat penyidik pembantu. Syarat kepangkatan penyidik pembantu lebih rendah dari pangkat jabatan penyidik. Berdasar hierarki dan oraganisatoris penyidik pembantu diperbantukan kepada pejabat penyidik, oleh karena itu kepangkatan mereka harus lebih rendah dari penyidik (Hamzah, Andi. 2004).

Setelah berlakunya undang-undang hukum acara pidana yang baru, maka terjadi perubahan yang fundamental didalam system peradilan pidana yang juga mempengaruhi pula system penyidikan. Di dalam KUHAP Pasal 6 ayat (1) huruf b telah ditentukan bahwa penyidik ada penyidik pegawai negeri sipil tertentu yang diberi wewenang khusus oleh undang-undang. Dalam Pasal 7 ayat (2) KUHAP yang menyatakan Penyidik Pegawai Negeri Sipil (PPNS) sebagaimana dimaksud Pasal 6 ayat (1) huruf b mempunyai wewenang sesuai dengan undang-undang yang menjadi landasan hukumnya masing-masing dan dalam pelaksanaan tugasnya berada dibawah koordinasi dan pengawasan penyidik Polri. Oleh karena itu timbul kajian yang lebih mendalam lagi mengenai adanya persoalan tentang apakah dalam melakukan proses penyidikan PPNS dalam prakteknya menemukan kendala atau hambatan Penyidik PPNS dalam melaksanakan tugas tersebut. Padahal wewenang Penyidik Pegawai Negeri Sipil tersebut (Prakoso, Djoko. 1988) adalah melakukan penyidikan yaitu tugas-tugas Kepolisian yang bersifat represif justisial, sehingga setelah lahirnya Penyidik Pegawai Negeri Sipil berdasarkan KUHAP, maka alat-alat kepolisian khusus tidak lagi berwenang melakukan tugas-tugas kepolisian yang bersifat judicial represif. Menurut Undang-Undang Nomor 18 Tahun 2013 Tentang Pencegahan dan Pemberantasan Perusakan Hutan sebagaimana bunyi pasal 1 angka 17 Pejabat Penyidik Pegawai Negeri Sipil, yang selanjutnya disingkat PPNS adalah pejabat pegawai negeri sipil tertentu dalam lingkup instansi kehutanan pusat dan daerah yang oleh undang-undang diberi wewenang khusus dalam penyidikan di bidang kehutanan dan konservasi sumber daya alam hayati dan ekosistemnya. Pasal 39 UU Nomor 5 tahun 1990 berbunyi "Selain Penyidik Pejabat Polisi Negara Republik Indonesia, PPNS diberi wewenang khusus sebagai penyidik sebagaimana dimaksud dalam Kitab Undang-Undang Hukum Acara Pidana." Sebagaimana dimaksud dalam Pasal 6 ayat (3) huruf a Perkap Nomor 20 Tahun 2010, tentang Koordinasi, Pengawasan dan Pembinaan Penhyidikan bagi PPNS yaitu memberitahukan dimulainya penyidikan dan menyampaikan hasil penyidikannya kepada penuntut umum setelah berkoordinasi dengan Penyidik Pejabat Polisi Negara Republik Indonesia. Untuk memperoleh bukti permulaan, penyidik 
dapat menggunakan laporan yang berasal dari masyarakat dan/atau instansi terkait.

Pengertian penyidikan sendiri dalam KUHAP menurut sebagian ahli hanyalah bersifat umum, karena saat ini banyak produk undang-undang yang telah dibuat dan didalamnya memberikan kewenangan bagi pejabat tertentu untuk melakukan tindakan penyidikan atau dengan kata lain dengan berkembangnya hukum nasional maka ketentuan yang lebih khusus telah diberikan melalui produk yakni undangundang khusus. Salah satu adalah adanya Undang-Undang No. 41 Tahun 1999 tentang Kehutanan yang memberikan kewenangan bagi pejabatnya untuk melakukan tindakan penyidikan (Mulyadi, Lilik, 2007). Pejabat yang dimaksud adalah Penyidik Pegawai Negeri Sipil, yang dalam ketentuan undang-undang tersebut dikatakan dapat melakukan tindakan terhadap tindak pidana yang dilakukan dibidang kehutanan. Pasal 1 ayat 1 KUHAP menyatakan proses penyidikan selama ini dilakukan oleh penyidik dari Kepolisian Republik Indonesia atau Pejabat Pegawai Negeri Sipil tertentu yang dilakukan berdasarkan undang-undang khusus untuk melakukan penyidikan. Namun dalam hal ini Pejabat Pegawai Negeri Sipil hanya diberikan wewenang sebatas apa yang diatur dalam undang-undang khusus mengatur tentang kewenangannya tersebut. Untuk dapat diangkat menjadi seorang penyidik maupun seorang yang dapat melakukan tindakan penyidikan (Lamintang, Theo, 2010) tidaklah sembarang orang, dalam arti bahwa ada persyaratan tertentu yang menyatakan bahwa untuk dapat diangkat menjadi seorang penyidik maka harus memenuhi persyaratan tertentu khususnya untuk menjadi Penyidik Pegawai Negeri Sipil.

Adapun salah satu contoh perkara yang terjadi di Tapanuli Tengah adalah Pada hari Kamis tanggal 27 April 2012 pukul 16.00 Wib di Jln. Tarutung Km. 5 terjadi tanah longsor yang yang menimpa dua unit rumah masyarakat sehingga rusak,kemudian jalan umum tertimbun material tanah, mengakibatkan akses jalan dari Medan ke Sibolga dan sebaliknya menjadi terputus. Penyebab tanah longsor diduga akibat dari penebangan pohon kayu di lereng perbukitan sekitar 300 meter dari jalan. Yang melakukan penebangan pohon kayu adalah Judiman Pardede. Sebagai tersangka dalam perkara Illegal Logging tersebut adalah Judiman Pardede yang yang berperan menebang pohon kayu dan Parasian Tarihoran (Kepala Desa Simaninggir) yang menerbitkan Surat Keterangan Tanah di dalam kawasan hutan lindung.

Bahwa Kepala Desa Tidak dapat menerbitkan Surat Keterangan Tanah Berdasarkan ketentuan pasal 24 Peraturan Pemerintah No.24 Tahun 1997 tentang Pendaftaran Tanah menyebutkan bahwa untuk keperluan pendaftaran tanah yang berasal dari hak-hak atas tanah yang berasal dari konversi hak-hak lama dibuktikan dengan alat-alat bukti mengenai adanya hak tersebut berupa bukti-bukti tertulis (Moeljatno, 1993), keterangan saksi dan atau pernyataan yang bersangkutan, maka dengan demikian dalam rangka pembuktian hak milik adat tersebut apabila tidak ada bukti tertulis tentang kepemilikannya maka seseorang yang merasa memiliki sebidang tanah tersebut untuk membuktikan telah memiliki tanah tersebut dapat membuat 
surat pernyataan pemilikan tanah, yang disaksikan oleh sekurang-kurangnya 2 (dua) orang saksi dan diketahui Kepala Desa (sesuai pasal 76 ayat 2 Peraturan Menteri Negara Agraria/Kepala Badan Pertanahan Nasional.

Faktor Yang Mempengaruhi Upaya Penyidikan Tindak Pidana Illegal Logging oleh Penyidik Polres Tapanuli Tengah

Pembalakan liar (Illegal Logging) terjadi karena adanya kerjasama antara masyarakat lokal berperan sebagai pelaksana dilapangan dengan para cukong bertindak sebagai pemodal yang akan membeli kayu-kayu hasil tebangan tersebut, adakalanya cukong tidak hanya menampung dan membeli kayu-kayu hasil tebangan namun juga mensuplai alat-alat berat kepada masyarakat untuk kebutuhan pengangkutan. Untuk mengatasi maraknya tindak pidana pembalakan liar (Illegal Logging) jajaran aparat penegak hukum (penyidik Polri maupun penyidik PPNS yang lingkup tugasnya bertanggungjawab terhadap pengurusan hutan (Nurdjana, IGM dkk. 2005).

Aktivitas pembalakan liar (Illegal Logging) dengan lebih terbuka, transparan dan diduga banyak pihak yang terlibat dan memperoleh keuntungan dari aktivitas pencurian kayu, modus yang biasanya dilakukan adalah dengan melibatkan banyak pihak. Pada umumnya, mereka yang berperan adalah buruh/penebang, pemodal (cukong), penyedia angkutan dan pengaman usaha (seringkali sebagai pengaman usaha adalah dari kalangan birokrasi, aparat pemerintah, polisi, dan TNI). Praktek pembalakan liar (Illegal
Logging) adalah pengusaha melakukan penebangan di bekas areal lahan yang dimiliki maupun penebangan diluar jatah tebang (over cutting) dan adakalanya pembalakan liar (Illegal Logging) dilakukan melalui kerjasama antara perusahaan pemegang izin Izin Usaha Pemanfaatan Hasil Hutan Kayu (IUPHHK) dengan para cukong. Seringkali pemegang izin meminjamkan perusahaannya untuk mengikuti lelang kayu sitaan kepada pihak cukong yang tidak ada hubungannya sama sekali dengan perusahaan tersebut.

1. Undang-undang.

Adanya undang-undang merupakan syarat yang dapat dihilangkan dalam mengatasi suatu permasalahan hukum. Apabila hukum tidak mengatur maka para pelanggar hak orang lain dapat dengan leluasa melakukan tindakan yang tidak semestinya ia lakukan. Akan tetapi adanya undang-undang pun kurang menjamin untuk menyelesaikan permasalahan hukum tersebut karena apabila adanya undang-undang justru menjadi tumpang tindih dari undang-undang yang lain. Penyidikan oleh PPNS Kehutanan yang selama ini berpedoman pada UndangUndang No. 41 tahun 1999 tentang Kehutanan merupakan dasar bagi PPNS Kehutanan untuk melakukan Penyidikan (Supriadi. 2010), namun dalam praktek yang ada sekarang justru kewenangan yang dilakukan tersebut kurang bersifat terintegrasi karena sesudah melakukan penyidikan dengan dasar undang-undang kehutanan PPNS Kehutanan wajib untuk melaksanakan ketentuan lain yang letaknya berada diluar undang undang kehutanan seperti pelimpahan berkas penyidikan kepada Penuntut Umum melaui pihak Kepolisian. Selain itu selama 
ini PPNS Kehutanan hanya diberikan tugas yang bersifat teknis seperti penangkapan terhadap seseorang yang diduga melakukan tindak pidana kehutanan dan proses penyidikannya tetap dilakukan oleh Penyidik Polri. Proses pelimpahan berkas tersebut dalam prateknya sering terdapat masalah sehingga Penuntut Umum mengembalikan berkas ke penyidik, dimana seringkali tidak diberitahukan oleh pihak kepolisian sewaktu pelimpahan berkas kepada Penuntut Umum. Hal ini dirasakan kurang terintegrasi seharusnya dari awal sudah ditentukan dalam satu undang-undang yang memberikan kewenangan kepada PPNS Kehutanan untuk melakukan penyidikan (keterintegrasian UndangUndang Kehutanan, Undang-Undang Kepolisian dan Undang-Undang Kejaksaan dalam hal koordinasi proses penyidikan menjadi hal mutlak adanya). Proses penyatuan produk hukum terkait menjadi satu merupakan hal yang sangat diperlukan guna memberikan pedoman yang mudah dalam pelaksanaannya akan tetapi tidak menghilangkan esensi dari tugas maupun wewenang penegak hukum tersebut.

2. Mentalitas aparat penegak hukum.

Lemahnya pengawasan dari aparat penegak hukum merupakan salah satu hal yang menjadikan faktor kedua ini muncul. Pengawasan diperlukan dengan tujuan untuk meminimalisir atau mencegah terjadinya suatu tindak pidana Illegal Logging di suatu kawasan hutan. Dengan kurangnya pengawasan dari aparat penegak hukum tersebut menyebabkan para pelanggar dengan leluasa mengekploitasi hasil hutan dengan semena-mena khususnya yang dilakukan oleh para cukong dengan beking atau bantuan dari aparat penegak hukum yang lain. Dalam hal ini kesadaran akan pelestarian hutan dari para aparat hukumnya sendiri dirasakan sangat kecil hanya untuk sejumlah uang mentalitas mereka menjadi taruhannya yakni tidak berani menindak hanya karena telah dibayar/disogok uang oleh para cukong tersebut (terbongkarnya kasus seorang perwira polisi di Jayapura yang mempunyai kekayaan berlimpah karena melakukan penyelundupan kayu illegal) (Ngandung, I B. 1975). Selain itu kurangnya keberanian dari para penegak hukum itu sendiri dalam menindak para pelaku tindak pidana kehutanan dengan alasan bahwa tidak ada aturan yang memayunginya yang sebenarnya para aparat penegak hukum harus nya mempunyai tindakan diskresi (kewenangan yang memang harus dilakukan karena tidak aturan yang mengaturnya) dimana selama ini hanya dipraktekkan oleh hakim (Artidjo Alkostar dalam memberikan hukuman maksimal kepada Terdakwa korupsi Angelina Sondakh) dalam memutus perkara tertentu. Perlunya tindakan diskresi merupakan awal pembangunan mentalitas dari para aparat penegak hukum dalam menindak pelaku tindak pidana kehutanan tersebut. Sehingga kesadaran dan keteguhan iman akan tertap terjaga pada setiap diri apara penegak hukum.

\section{Perilaku masyakarat / kultur.}

Masyarakat yang menjadi faktor penentu dalam pelestarian kawasan hutan. Masyarakat seharusnya tidak terlibat dalam lingkaran permasalahan tindak pidana kehutanan karena mereka lah yang secara langsung mempunyai kewajiban 
untuk menjaga dan melestarikan kawasan hutan khususnya mereka yang tinggal dekat atau didalam kawasan hutan. Perilaku masyarakat yang semakin berkembang justru membawa dampak buruk dengan dalih bahwa kebutuhan akan perut atau hanya sekedar (Ngandung, I B. 1975) memenuhi keinginan nafsu dunia mereka dengan sengaja merelakan hutan yang seharusnya menjadi bagian penting dalam kehidupan dunia harus dijarah demi kepentingan kelompok tertentu yang tidak bertanggung jawab. Hilangya rasa akan pentingnya pelestarian hutan mengakibatkan kawasan hutan di Indonesia kini semakin memprihatinkan sebagai contoh sering terjadinya banjir bandang dan tanah longsor seperti didaerah Pulau Sumatera, Kalimantan, Sulawesi dan yang terbesar pernah terjadi tahun 2013 di Jayapura dimana kota tersebut banjir bandang yang material bongkohan kayu-kayu besar yang berasal dari dataran tinggi.

Proses penanaman nilai-nilai pelestarian hutan sejak dini pun dirasa kurang atau masih belum dapat mengubah perilaku masyarakat yang sudah berubah ke arah modernisasi dengan kedok pembangunan masyarakat industri (industrialisasi) (Ngandung, I B. 1975).

Permasalahan mendasar yang dihadapi bagi penegak hukum dalam memberantas Illegal Logging disebabkan Illegal Logging termasuk dalam kategori kejahatan yang terorganisir,yaitu ada actor intelectualnya, ada pelaku materialnya. Pelaku material bisa buruh penebang kayu yang hanya diupah, pemilik modal (cukong), pembeli, penjual dan acapkali ada backing dari oknum TNI atau Polri, aparat pemerintah maupun tokoh masyarakat. Di antara mereka selalu bekerja sama secara rapi, teratur dan solid. Disinyalir ada yang membackingi, sehingga praktek Illegal Logging sangat sulit diberantas, dan kalaupun ditemukan kasusnya yang dipidana bukan actor intelectual atau cukong, hanya pelaku biasa seperti penebang kayu, pengemudi, atau nakhoda kapal yang menjalankan kenderaannya. Pelaku sebenarnya sudah kabur duluan sebelum petugas penegak hukum dapat menangkapnya. Kegiatan penebangan kayu secara liar (Illegal Logging) telah menyebabkan berbagai dampak negatif dalam berbagai aspek, sumber daya hutan yang sudah hancur, selama masa orde baru kian menjadi rusak akibat maraknya penebangan liar dalam jumlah yang sangat besar.

Berkaitan dengan adanya faktorfaktor yang telah diuraikan diatas maka menjadi suatu yang penting dalam melakukan suatu penegakan hukum yang sesuai dengan kaidah-kaidah (Zain, Alam Setia. 2000) yang hidup dalam masyarakat dimana penegakan hukum selalu akan melibatkan manusia didalamnya dan dengan demikian akan melibatkan tingkah laku manusia juga. Hukum tidak bias tegak dengan sendirinya, artinya ia tidak akan mampu mewujudkan janji-janji serta kehendakkehendak yang tercantum dalam hukum tersebut. Penegakan hukum dalam hal ini ialah yang berkaitan dengan tugas penyidikan yang dilakukan oleh Penyidik Pegawai Negeri Sipil bahwa amanat yang telah diberikan oleh undang-undang memang memberikan kewajiban bagi dirinya namum dalam pelaksanaannya selalu saja terdapat masalah yang dihadapi. Tinggal bagaimana menatalitas dari penegak hukum (Penyidik Pegawai 
Negeri Sipil) itu sendiri dalam menerapkan bunyi undang-undang karena kata sebagian orang tugas yang dimilki oleh penegak hukum tersebut masih tumpang tindih dengan penegak hukum yang lain (Kepolisian), namun secara umum sendiri tidak ada kendala dalam melakukan tugas penyidikan karena secara peraturan yang telah ada sudah jelas pemberian wewenang yang diberikan oleh Undang-Undang Kehutanan saat ini. Adanya faktor yang menyebabkan semakin maraknya pembalakan liar/ Illegal Logging merupakan faktor yang penyebabnya itu sendiri berasal dari keinginan menguasai yang berlebihan. Faktor-faktor tersebut diatas merupakan faktor umum(general) yang menjadi penyebab terjadinya Illegal Logging di Indonesia (Zain, Alam Setia. 2000).

\section{SIMPULAN}

Pelaksanaan penyidikan tindak pidana kehutanan antara lain, masih terdapat kekurangan peraturan perundang undangan mengenai tindak pidana ini, antara lain belum ada penetapan kawasan hutan, karena selama ini hanya ada penunjukan kawasan hutan dengan Surata Keputusan Menteri Kehutanan yang pelaksanaannya menimbulkan kontroversi. Sarana dan prasarana di tingkat penyidikan Polri masih kurang, diantaranya kenderaan tidak ada, hanya mengandalkan kenderaan dinas konvensional, karena bukan khusus untuk kenderaan tugas ke pedalaman. Partisipasi dari masyarakat dalam upaya pelaksanaan penyidikan tindak pidana Illegal Logging masih kurang, kalau hanya mengharapkan petugas Polri saja tidak mampu, karena luas wilayah dengan jumlah personil Polri tidak seimbang, banyak terdapat perbedaan presepsi batas sepadan antara tanah ulayat dengan hutan Negara (hutan lindung), serta tempat atau medan yang sulit untuk ditempuh dalam melaksanakan penyidikan tindak pidana Illegal Logging.

Upaya yang dilakukan oleh penyidik Polri untuk mengatasi kendala yang ditemui dalam pelaksanaan penyidikan antara lain, mengintensifkan koordinasi, pengawasan dan kegiatan patroli bersama dengan aparat terkait dikawasan yang tingkat Illegal Logging nya tinggi. Memberikan keyakinan dan perlindungan hukum kepada aparat penyidik PPNS maupun kepada masyarakat agar dapat berpatisipasi dengan aparat penyidik Polri dalam membantu pelaksanaan penyidikan tindak pidana Illegal Logging. Membutuhkan tambahan sarana dan prasarana yang masih kurang di Polres Tapanuli Tengah, luas wilayah yang tidak seimbang dengan jumlah penyidik Polri yang ada di Polres Tapanuli Tengah, perbedaan persepsi antara tanah ulayat dan hutan lindung, dan tempat atau medan yang sangat sulit untuk ditempuh serta memanfaatkan semua sumber daya yang ada secara oftimal.

\section{DAFTAR PUSTAKA}

\section{A. Buku-buku}

Idris, Saring. 1993. Pengukuhan Hutan dan AspekAspek Hukum (Suatu Analisa Yuridis) Bagian I. Bahan Penataran Teknis-Yuridis Kawasan Hutan 1992/1993.

Data Polres Tapanuli Tengah dalam perkara Illegal Logging.

Soekanto Soeryono, Pengantar Penelitian Hukum, Universitas Indonesia (UI Pres), 2012.

Hasanah, Sovia, S.H Bisakah dihukum jika menebang kayu hutan di dekat rumah: 09 November 2016. 
Soerodibroto, Soenarto. 2007. KUHP dan KUHAP dilengkapi Yurisprudensi Mahkamah Agung dan Hoge Raad, PT. Raja Grafindo Persada: Jakarta.

Suarga, Riza. 2005. Pemberantasan Illegal Logging, Optimisme di Tengah Praktek Premanisme Global, Wana Aksara: Tangerang.

Hamzah, Andi. 2004. Asas-asas Hukum Pidana, PT. Rineka Cipta.

Prakoso, Djoko. 1988. Hukum Penitensier di Indonesia, Liberty: Yogyakarta.

Mulyadi, Lilik. 2007. Putusan Hakim dalam Hukum Acara Pidana, PT. Citra Aditya Bakti: Bandung.

Lamintang, Theo. 2010. Hukum Penitensier Indonesia. Edisi Kedua. Penerbit Sinar Grafika

Moeljatno. 1993. Asas-asas Hukum Pidana, PT. Rineka Cipta: Jakarta.

Nurdjana, IGM dkk. 2005. Korupsi dan Illegal Logging dalam Desentralisasi Indonesia. Yogyakarta. Pustaka Pelajar.

Supriadi. 2010. Hukum Kehutanan \& Hukum Perkebunan di Indonesia. Jakarta. Sinar grafika.

Ngandung, I B. 1975. Ketentuan Umum Pengantar Hutan dan Kehutanan Indonesia. Pusat Latihan Kehutanan: Ujung Pandang.

Zain, Alam Setia. 2000. Hukum Lingkungan Konservasi Hutan dan Segi- segi Pidana, PT. Rineka Cipta: Jakarta.

\section{B. Peraturan Perundang-undangan}

Kitab Undang-undang Hukum Pidana.

Kitab Undang-undang Hukum Acara Pidana.

Undang-undang Republik Indonesia Nomor 5 tahun 1967 tentang Pokok- pokok Kehutanan Indonesia.

Undang-undang Republik Indonesia Nomor 20 tahun 1947 tentang Hukuman Tutupan.

Undang-Undang No. 32 Tahun 2009 tentang Perlindungan dan Pengelolaan Lingkungan Hidup.

Undang-undang Republik Indonesia Nomor 41. Tahun 1999 tentang Kehutanan.

Undang-undang Republik Indonesia Nomor 50. Tahun 1990 tentang Konservasi Sumber Daya Hayati dan Ekosistemnya.

Instruksi Presiden Republik Indonesia Nomor No.5 Tahun 2001 tentang Pemberantasan Penebangan Kayu Illegal (Illegal Logging). 